\title{
The impacts of rail transit on property values: Empirical study in Beijing

\author{
Yizhen $\mathrm{Gu}$
}

\author{
Department of Planning Research, Beijing Municipal Institute of City Planning \& Design \\ Room 2005, No.60, South Lishi Road, Beijing, 100045, China
}

\begin{abstract}
Though most studies confirm the positive impacts of the rail transit on property values, a few studies report the insignificant impacts. It is suggested that the submarket effect is an important factor that causes the mixed conclusions. Using hedonic price method, our empirical study on Batong line of Beijing verifies this idea. The article also puts forward that the submarket effect is the integration of two opposite effects. The Effect $I$, which comes from the convexity of bid-rent curve, causes the greater impact of the rail transit in CBD than that in suburb. However, the Effect II originating from the law of diminishing marginal returns produces the opposite impact. The difference between the bid-rent gradients of the commercial and office sector and that of the residential essentially shifts the relative magnitude of these two effects. As for the commercial and office property, the impact of the Effect $I$ is greater than that of Effect II, that causes the value premium higher in CBD than that in suburb. While for the residential, the impact of Effect II dominates so the premium in suburb is higher.
\end{abstract}

Keywords: Rail transit; Property value; Hedonic price method; Submarket

\section{Introduction}

The relationship between transportation cost and land value is one of the basic concerns of urban economics. Based on the basic model in urban economics, the decrease in transportation cost to urban center will directly increase the residents' bids for land and thus raise land values (Alonso, 1964). Therefore, the rail transit causes great external benefits by increasing the nearby property values. At the same time, there exists a problem of fund shortage and fiscal burden facing urban rail transit construction. The early report showed that the fiscal subsidy of rail transit by Beijing municipal government amounted to about 400 million yuan every year (He and Jin, 2001). While according to related plan, the total length of rail transit of Beijing will increase from the present $114 \mathrm{~km}$ to more than $1,000 \mathrm{~km}$ in the future. So Beijing municipal government has always been seeking how to internalize the external benefit of rail transit in order to raise enough money. For this, the primary issue is to evaluate the impacts of the rail transit on property values.

The literature review tells us that though most studies confirm the positive impacts of the rail transit on property values, a few studies report the insignificant impacts. Kim and Zhang (2005) consider that the submarket effect is the important factor which causes the mixed conclusions. As for the rail transit, the submarket effect means its impact is different at different locations. Thus the geographical distribution of samples will have great effects on the results. If we sample disproportionately much in the area where the impact is weak, it is possible for us to draw a conclusion that the impact of rail transit is insignificant.

Kim and Zhang (2005) explain what causes the submarket effect using bid-rent model. They also put forward that the impact of rail transit is greater in CBD than that in suburb. This is confirmed by their empirical study on the commercial properties in Seoul, Korea. But quite a few researchers hold the opposite view, because they think the decrease in marginal transportation cost caused by rail transit in CBD is less than that in suburb.

After the introduction of the literature in the following, this study suggests a theoretical background that explains the submarket effect by integrating the above two viewpoints. Then, examining 141 house prices nearby Batong Line in Beijing, China, this study validates the submarket effect of rail transit's impacts: Batong Line has significant impacts on the residential property values in suburb while the impact is weak near the urban centre, which makes the impact insignificant in the whole study area. Combined with theoretical analysis, we guess that the submarket effect of rail transit's impact exhibits different characteristics for different types of properties. As for the commercial and office property, the value premium produced by rail transit is higher in CBD than that in suburb. While for the residential, it is just 
the reverse.

\section{Literature Review}

There is vast literature on the impacts of rail transit on urban real estate market. Most studies find that the rail transit has positive effect on property values. About the housing, Benjamin and Sirmans (1996) show that residential rents decreased by $2.4 \%$ to $2.6 \%$ for each one-tenth mile in distance to a metro station in Washington D.C. Al-Mosaind, Duecker and Strathman (1994) find that property values were higher by $10.6 \%$ within 500 meters of railway stations two years after the operation of railway in Portland. The research in Shenzhen, China (Zheng and Liu, 2003) also confirms the significant impacts of rail transit. Unlike the housing studies, there have been very few studies of the capitalization benefits of proximity of rail transit to commercial and office properties (Kim and Zhang, 2005). Diaz (1999) reports that some commercial land values along the railway in Washington D.C. rose by $100 \% \sim 300 \%$.

However, a few studies draw contrary conclusions. Gatzlaff and Smith (1993) reveal that the Miami Metrorail has weak impact on single-family property values. A study by Cervero and Landis (1993) on Atlanta and Washington D.C. and another study by Landis et al. (1995) on San Francisco find small or no impacts on commercial properties.

For theses mixed conclusions, the researchers have listed possible explanations: The impact of rail transit is different on different types of properties; The impact varies during different periods such as planning, construction and operation; The impact depends on the service quality of rail transit; As for housing, there is negative impact like noise near the railway station; As for commercial properties, the value premiums are correlated with land use policies (Nelson, 1999).

However, the conflict results cannot be fully explained only by these reasons. It is put forward that the submarket effect is an important factor that causes this phenomenon (Kim and Zhang, 2005). A submarket is typically defined as a geographic area where the price per unit of housing quantity is internally constant but differs substantially from others (Goodman and Thibodeau, 1998). As for rail transit, the submarket effect means that the price of the amenity, accessibility to railway station, varies by locations. Therefore, the results will greatly depend on the geographic distribution of sample properties. If we sample disproportionately much in the area where the impact of rail transit is weak, it is possible for us to draw a conclusion that the impact is insignificant.

It is generally accepted that the impact of rail transit on property values in suburb is greater than that in urban center (e.g. Wang et al., 2004). While based on the bid-rent model, Kim and Zhang (2005) theoretically demonstrate that the value premium caused by rail transit is highest in center area with higher density. Their empirical study on commercial properties in Seoul also confirms this idea. However, an important issue, that the decrease in marginal transportation cost resulted from rail transit in CBD is usually less than that in suburb, is neglected in their demonstration. So, at which location the impact is greater, and what determines the relative magnitude of rail transit's impact, need to be further studied.

In addition, spatial econometrics has been applied in housing research in recent years. Different from the traditional econometrics, spatial econometrics mainly deals with two issues caused by the location attributes of samples: spatial dependency between sample data observations at various points in space; and spatial heterogeneity that arises from model parameters that vary with sample data as we move through space (Lesage, 1999).

In the real estate market, discriminately and unidentically distributed location attributes cause property values to be dependent upon nearby property values and the regression errors to be autocorrelated by the location. This is called spatial autocorrelation (Kim and Zhang, 2005). Spatial econometrics has developed several methods to deal with this issue. Kim and Zhang (2005) use multiple methods such as OLS, SAC, etc. to evaluate the impacts of rail transit in Seoul. They find that spatial models all outperform the OLS estimation in the presence of spatial autocorrelation, and SAC model performs best among these spatial models.

Spatial heterogeneity in the real estate market implies that model parameters will vary with locations for the existence of submarkets. So the characteristics of the variation over space of the parameters should be specified. However, it is very difficult to specify the boundary of submarkets accurately. The study in Seoul by Kim and Zhang (2005) just arbitrarily sets four round submarkets with the radius of $2 \mathrm{~km}$ to show the presence of submarket effect. 


\section{Theoretical analysis on submarket effect}

In this section, we will try to find out what causes the variance of the impacts of rail transit and especially the submarket effect based on the bid-rent model (Alonso, 1964). A convex land bid-rent curve in a monocentric city is depicted as in Figure 1. Suppose a rail line from CBD to suburb has been put into operation in this city, and one of the railway stations is located in $\mathrm{x}_{1}$, then, by decreasing the transportation cost from $x_{1}$ to CBD, the rail line will raise the rent of properties in $x_{1}$ from $R_{1}$ to $R_{2}$ (shown in red broken line in Figure 1). Now, the rent of properties in $\mathrm{x}_{1}$ equals to the rent of properties in $\mathrm{x}_{2}$ (closer to CBD) when there is no rail line. So, the rail transit is considered to reduce the distance from certain location to $\mathrm{CBD}$. In the following, we will use the decrease of the distance to $C B D$ to represent the function of rail transit ${ }^{1}$.

Additionally, rail transit also raises the rent of properties nearby this station, which is increasing in $x$ when $\mathrm{x}<\mathrm{x}_{1}$ and decreasing in $\mathrm{x}$ when $\mathrm{x}>\mathrm{x}_{1}$ (illustrated as red curve line in Figure 1). Obviously, the form of the bid-rent curve becomes more complicated because of the rail transit. Fortunately, the purpose of this study is just to explain the submarket effect (the relative length of red broken lines at different locations), so there is no need to present the actual bid-rent curve in our analysis. Also, in order to make the figures more clear, we omit the red broken line and use the equivalent blue broken line instead to show the impacts of rail transit on property values just at the station location (see Figure 1).

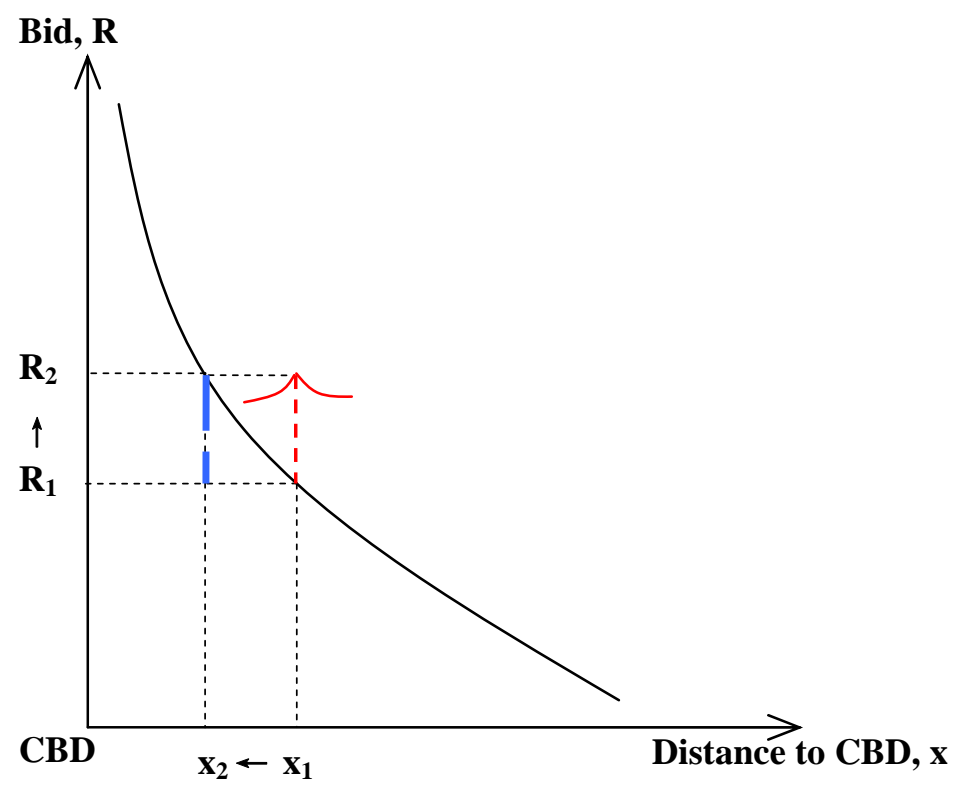

Figure 1: The impact of rail transit on property values

Above all, the economic impacts of rail transit on different types of properties will be investigated. The bid-rent curves of three different sectors, commercial \& office, residential and industrial, in a monocentric city can be seen in Figure 2 (Alonso, 1964; O'Sullivan, 2002). These three curves are all convex. The bid-rent curve of commercial and office sector is steeper than that of the residential, and the curve of the residential is steeper than that of the industrial sector. In such a city, the commercial and office sector locates in the urban center, the industrial sector situates in the outer suburb, and the residential sector locates between them.

As seen in Figure 2, at the same location, the value premium of commercial and office properties, $\Delta \mathrm{R}_{\mathrm{c}}$, is highest, the premium of residential properties, $\Delta \mathrm{R}_{\mathrm{r}}$, is less, and that of industrial properties, $\Delta \mathrm{R}_{\mathrm{i}}$, is least because of the different gradients of bid-rent curves, when the distance to CBD all decreases by $\Delta \mathrm{x}$ (representing the function of rail transit).

\footnotetext{
${ }^{1}$ This helps to explain submarket effect more clearly. Though unprecise, it has no substantial effect on our analysis.
} 


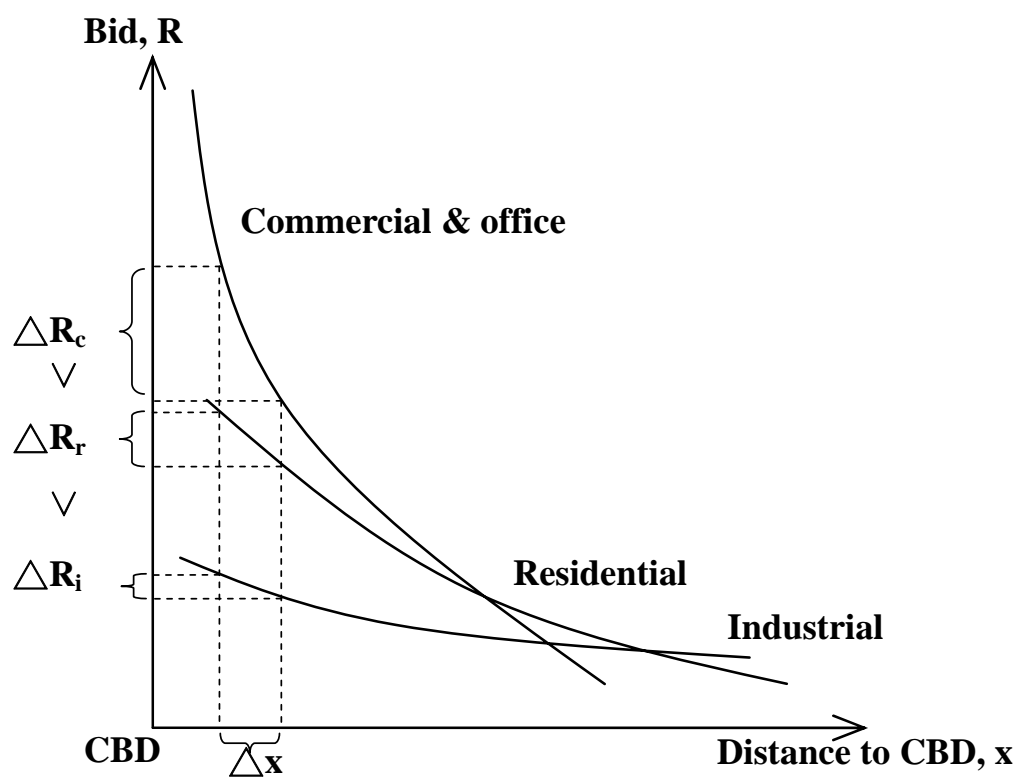

Figure 2: The impacts on different property types

Then we will try to explain what causes submarket effect. As seen in Figure 3, for a single type of properties, the value premium of properties in CBD resulted from rail transit, $\Delta \mathrm{R}^{\mathrm{c}}$, is higher than that in suburb, $\Delta \mathrm{R}^{\mathrm{s}}$, for the convexity of bid-rent curve when the distance to CBD both decreases by $\Delta \mathrm{x}\left(\Delta \mathrm{x}^{\mathrm{c}}=\right.$ $\left.\Delta \mathrm{x}^{\mathrm{s}}\right)$. This is called Effect $I$. In fact, it is based on the above argumentation that Kim and Zhang (2005) put forward their viewpoint. However, as we have mentioned, an important issue is neglected in their demonstration. For the disproportionately distribution of transportation infrastructure in the city, according to the law of diminishing marginal returns, the decrease in marginal transportation cost resulted from rail transit in urban center is less than that in suburb ${ }^{2}$. In other words, the reduced distance to CBD by rail transit in suburb, $\Delta \mathrm{x}^{\mathrm{s}}$, is greater than that in CBD, $\Delta \mathrm{x}^{\mathrm{c}}$. Thus, if the bid-rent curve is a straight line, the value premium of properties in suburb, $\Delta \mathrm{R}^{\mathrm{s}}$, will be higher than that in CBD, $\Delta \mathrm{R}^{\mathrm{c}}$. This is called Effect II. As seen in Figure 5, for the coexistence of these two effects, we cannot ascertain the relative magnitude of the impacts of rail transit in CBD and in suburb. However, because in general it is impossible for these two opposite effects to offset totally, the impacts of rail transit on property values will vary with locations.

In the following, for different types of properties, we will further discuss the integrated impacts of Effect I and Effect II , and thus the different exhibitions of submarket effect.

\footnotetext{
${ }^{2}$ We have to admit that this argumentation is lack of empirical evidence.
} 


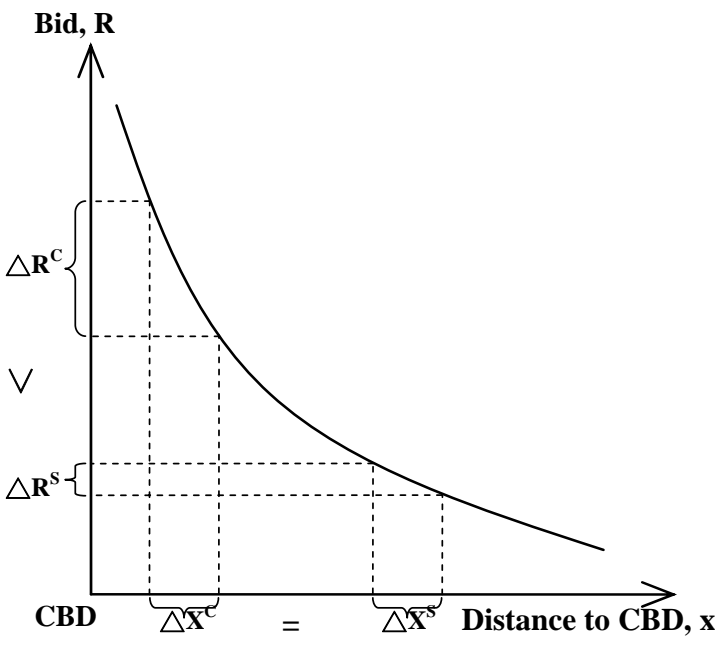

Figure 3: Effect I

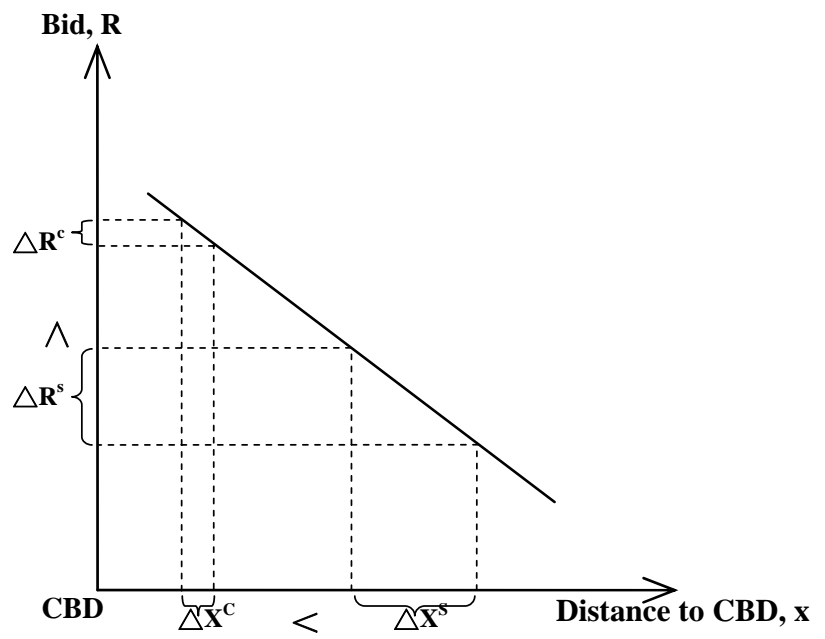

Figure 4: Effect II

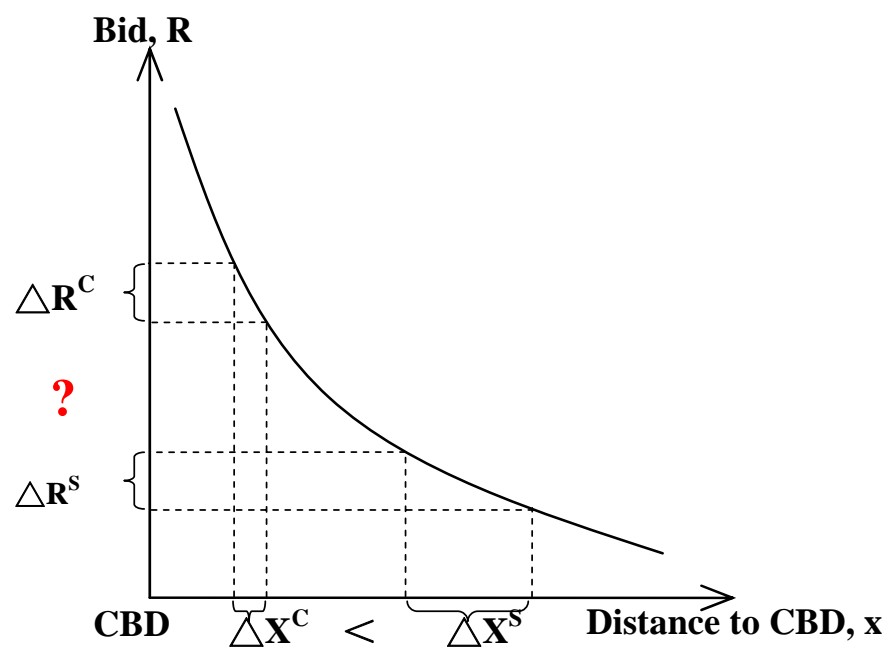

Figure 5: Integration of Effect I and Effect II

\section{Context}

Now there are four railway lines in operation in Beijing, and the total length is $114 \mathrm{~km}$ (see Figure 6). By the end of 2003, the annual passenger traffic of rail transit amounts to 472 million person-times, which accounts for 11 percent of the public passenger traffic. The four lines include: Metro No. 1 (put into operation in 1/10/1969, while Fuba segment later in 28/9/1999); Metro No. 2 (27/12/1987); Metro Batong Line (27/12/2003); Metro No.13 (west line in 28/9/2002, east line in 28/1/2003).

The extensive development of the real estate market in Beijing began in 1998. At that year, the central government of China abrogated the planed distribution of housing and enacted the financial policy of housing mortgage loan. Hereafter, it is possible for us to get abundant data on housing market prices. Therefore, of the four railway lines, we choose to study Batong line, which was put into operation latest. 


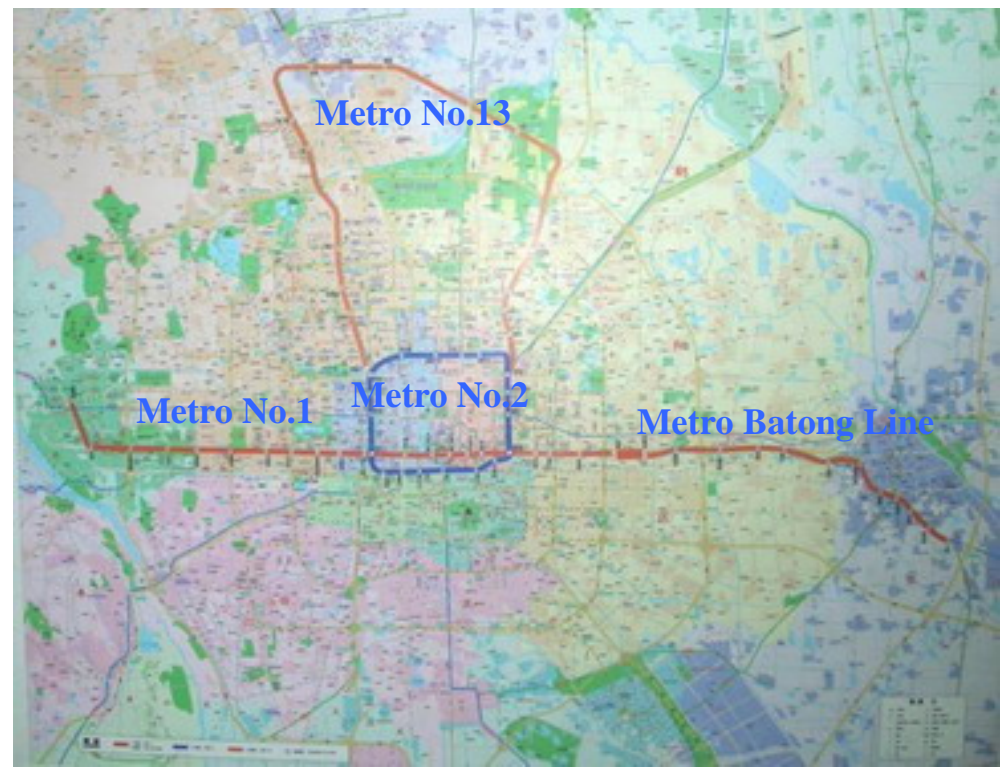

Figure 6: Rail transit in central city of Beijing

Batong line stretches across Chaoyang district (closer to urban center) and Tongzhou district of Beijing. It extends from $\mathrm{CBD}^{3}$ in Chaoyang eastward to Tongzhou and turns to the southeast after entering Tongzhou district ${ }^{4}$. The length of this line is $18.95 \mathrm{~km}$, and there are totally 13 stations from Sihui station to Tuqiao Station, which equals to one station per $1.6 \mathrm{~km}$. The plan and construction of Batong line began in 1993 and December 2001 respectively. The information on the location of railway stations had been open to the public no later than May $2002^{5}$. In December 2002, Batong line was put into operation formally. According to the early report, the daily passenger traffic amounts to more than 50,000 person-times, greatly lower than the expectation $(\mathrm{Li}, 2005)$.

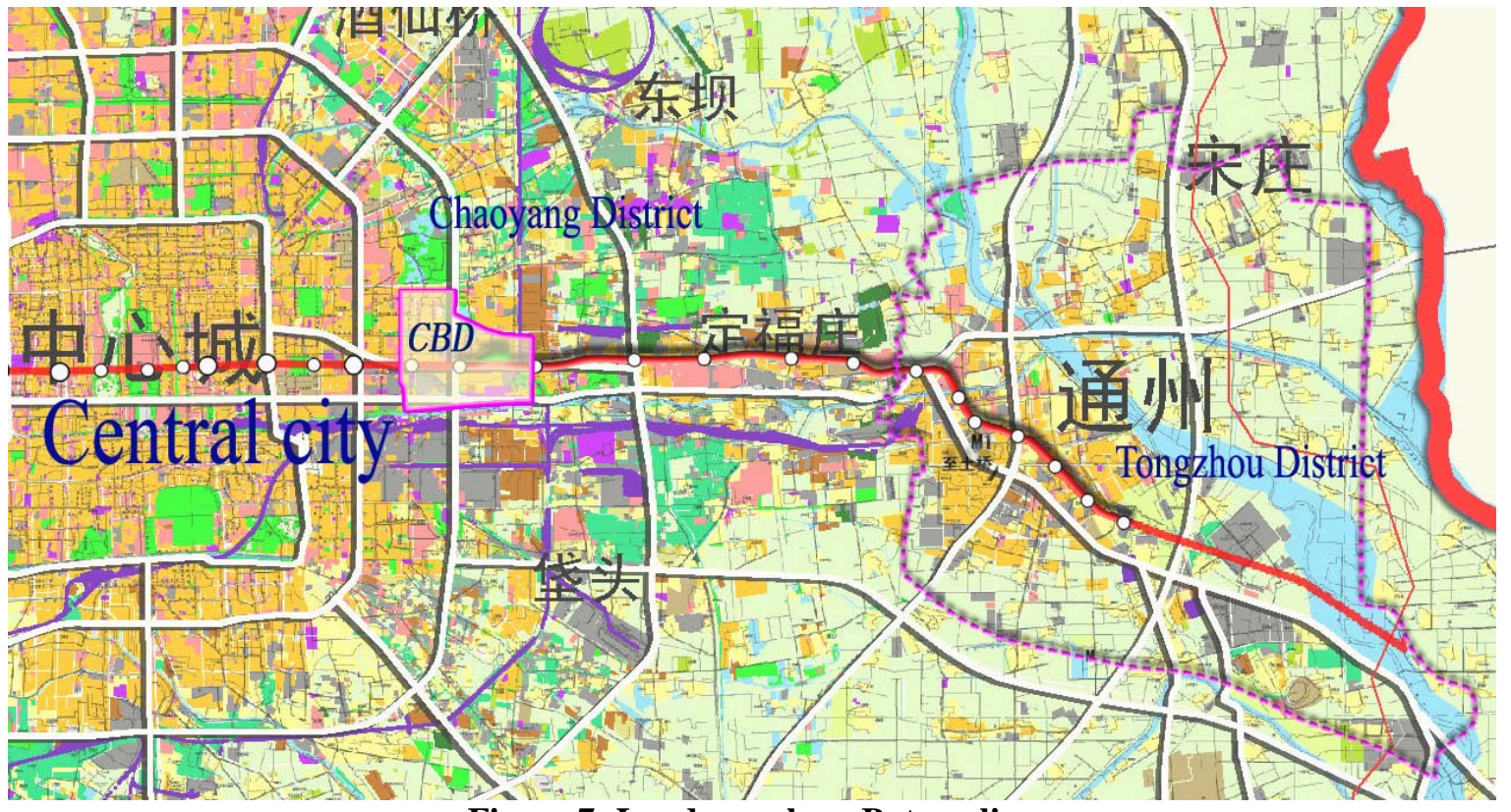

Figure 7: Land-use along Batong line

\footnotetext{
${ }^{3}$ Note that CBD here doesn't conform to the concept of CBD in urban economics. We will explain it later.

4 The original plan selects the south area of Tongzhou as main development area. So Batong line doesn't directly extend to the east to link the urbanized area of Tongzhou.

5 A planner involved said the plan had been publicized early in 2000, but according to our interview with some housing brokers and the news review, we finally choose May 2002. The figure of Batong line could be seen in a report at $\mathrm{http} / /$ house.sina.com.cn as early as in 15, May, 2002. And the frequency of news or reports on Batong line was obviously high in April or May of 2002.
} 
The land use along Batong line is shown in Figure 7. As seen in it, the ratio of residential land along this line is relatively high. In particular there are a lot of new residential areas developed in recent years. This will help to acquire abundant sample data.

\section{Method}

Housing, also its most important character, is a differentiated product. Hedonic price method and Repeat sale method are both developed to deal with this issue. Considering the data accessibility, we have to use the hedonic method. Also, the focus of this research is just housing.

A semi-log hedonic equation is adopted ${ }^{6}$ :

$$
\log \mathrm{P}=\mathrm{c}+\sum \mathrm{a}_{\mathrm{s}} \mathrm{x}_{\mathrm{s}}+\sum \mathrm{a}_{\mathrm{n}} \mathrm{x}_{\mathrm{n}}+\sum \mathrm{a}_{\mathrm{l}} \mathrm{x}_{1}+\mathrm{a}_{0} * \text { Rail }+\varepsilon,
$$

where $\mathrm{P}$ denotes the sale price of housing; $\mathrm{x}_{\mathrm{s}}, \mathrm{x}_{\mathrm{n}}$ and $\mathrm{x}_{1}$ represents the structure variables, the neighborhood variables and the location variables respectively; Rail is the variable capturing the impacts of rail transit; $a_{s}$, $\mathrm{a}_{\mathrm{n}}, \mathrm{a}_{1}$ and $\mathrm{a}_{0}$ are the coefficient estimates.

For the independent variable $\mathrm{P}$, most studies adopt the sale price of single house. However, it is difficult to get this kind of data in Beijing. Moreover, when selling the housing, the developer in Beijing will generally give the average sale price of the whole residential area based on gross economic reckoning, then the prices of every house in this residential area will be calculated according the adjustment coefficients that integrate such factors as floor, view and sunlight. So if the single house is used as samples, much unnecessary work, e.g. estimating the adjustment coefficients given by developers, will be added ${ }^{7}$. Therefore, this study uses the initial average sale price of new residential areas as the independent variable $^{8}$.

To analyze the submarket effect of rail transit' impacts, we design three equations. Equation 1 is a general equation without considering submarket effect. This equation includes three location variables: distance from the new residential area to CBD, distance to Tian'anmen Square ${ }^{9}$ and distance to railway stations ${ }^{10}$. Equation 2 divides the samples into two submarkets of Chaoyang and Tongzhou, including the dummy variable TZ representing Tongzhou submarket, and interactive variables CYD (CY*DSTA) and TZD (TZ*DSTA) evaluating the impacts of rail transit in different submarkets. Equation 3 further divides the samples into three submarkets: west to the $5^{\text {th }}$ ring road in Chaoyang (CYW), east to the $5^{\text {th }}$ ring road in Chaoyang (CYE), and Tongzhou. Similarly, equation 3 consists of two location variables, TZ and CYE, and interactive variables, CYWD, CYED and TZD evaluating the impacts of rail transit.

Additionally, the common variables used by all three equations include: structure variables: housing types of residential areas ${ }^{11}$, with decoration or not, and waiting time before the delivery of housing; neighborhood variables: floor-to-area ratio, green coverage ratio, property service fee, distance to park, distance to water, distance to high school, distance to hospital, distance to business facilities; location variables: distance to trunk road; others: sale time. Variable definitions and data sources are shown in Table 1.

\footnotetext{
${ }^{6}$ Compared with the linear equation and the log equation, the semi-log equation here has a better explanation capacity and the parameters estimated comply with our expectation better.

7 But we don't deny the possibility and significance of using data on the sale price of the existing housing stock.

${ }^{8}$ The average sale price will change with time. Based on our interview with housing brokers and actual observation, the earliest price of new residential areas, provided by real estate websites is most precise, while the latest price may be lower than the normal for including some unmarketable housing of low quality.

9 Tian'anmen Square is the geographic center of Beijing, and CBD in Chaoyang is just one of the high-density employment areas in the central city of Beijing. But as for residents along the Batong line, CBD is the most important employment area compared with other areas like Zhongguancun. The survey by Horizon Research Consultancy Group in 2005 shows that of residents in Tongzhou using rail transit as commute vehicle, nearly $90 \%$ live in the urbanized area of Tongzhou but work outside Tongzhou (mainly in Chaoyang). Hereby, these two variables are both chosen to describe the location of a residential area.

${ }_{10}$ About the form of the variable Rail, Knaap, Ding and Hopkins (2001) indicate that there are two approaches. One is using a continuous measure of distance to a station. Another is using dummy variable, that is, whether housing locates within certain radius of railway stations. This research adopts a continuous variable.

${ }^{11}$ Four types, such as villa, slab-type building, tower, and mix of slab-type and tower, are included. Professor Gao indicated that villa should be eliminated from samples for different demand and market. We will amend it in future research.
} 
Table 1: Variable definitions and data sources

\begin{tabular}{|c|c|c|c|c|c|c|c|}
\hline \multicolumn{3}{|c|}{ Category } & \multicolumn{2}{|c|}{ Variable } & Unit & Definition & $\begin{array}{c}\text { Data } \\
\text { source }\end{array}$ \\
\hline \multicolumn{3}{|c|}{ Dependent } & \multicolumn{2}{|c|}{ PRICE } & Yuan $/ \mathrm{m}^{2}$ & $\begin{array}{l}\text { Initial average sale price of a } \\
\text { new residential area }\end{array}$ & $\begin{array}{l}\text { Real } \\
\text { estate }\end{array}$ \\
\hline \multirow{26}{*}{ Independent } & \multirow{15}{*}{ Common } & Other & \multicolumn{2}{|c|}{ TIME } & & $\begin{array}{l}\text { Month of sale; continuous } \\
\text { variable, where } 1=\text { January } \\
1998\end{array}$ & Websites \\
\hline & & \multirow{5}{*}{ Structure } & \multirow{3}{*}{$\begin{array}{l}\text { Housing } \\
\text { type }\end{array}$} & VILLA & & $\begin{array}{l}\text { Dummy variable indicating } \\
\text { that housing type in a } \\
\text { residential area is villa ( } 1=\text { yes) }\end{array}$ & \multirow{3}{*}{ Websites } \\
\hline & & & & SLAB & & $\begin{array}{l}\text { Dummy variable indicating } \\
\text { that housing type in a } \\
\text { residential area is slab-type } \\
\text { building (1=yes) }\end{array}$ & \\
\hline & & & & MIX & & $\begin{array}{l}\text { Dummy variable indicating } \\
\text { that housing type in a } \\
\text { residential area is mix of } \\
\text { slab-type and tower }(1=\text { yes })\end{array}$ & \\
\hline & & & \multicolumn{2}{|c|}{ DECO } & & $\begin{array}{l}\text { Dummy variable indicating } \\
\text { that housing in a residential } \\
\text { area is with decorations (1= } \\
\text { yes) }\end{array}$ & Websites \\
\hline & & & \multicolumn{2}{|c|}{ WAIT } & Month & $\begin{array}{l}\text { Months between purchasing } \\
\text { and delivery }\end{array}$ & Websites \\
\hline & & \multirow{8}{*}{ Neighborhood } & \multicolumn{2}{|c|}{ FAR } & & Floor-to-area ratio & Websites \\
\hline & & & \multicolumn{2}{|c|}{ GREEN } & $\%$ & Green coverage ratio & Websites \\
\hline & & & \multicolumn{2}{|c|}{ FEE } & $\begin{array}{c}\text { Yuan/ } \\
\mathrm{m}^{2} \cdot \text { month }\end{array}$ & $\begin{array}{l}\text { Property service fee (using the } \\
\text { average if there are multiple } \\
\text { levels) }\end{array}$ & Websites \\
\hline & & & \multicolumn{2}{|c|}{ DPARK } & meter & Distance to the nearest park & GIS \\
\hline & & & \multicolumn{2}{|c|}{ DWAT } & meter & $\begin{array}{l}\text { Distance to the nearest river or } \\
\text { lake }\end{array}$ & GIS \\
\hline & & & \multicolumn{2}{|c|}{ DSCH } & meter & $\begin{array}{l}\text { Distance to the nearest high } \\
\text { school }\end{array}$ & GIS \\
\hline & & & \multicolumn{2}{|c|}{ DHOS } & meter & Distance to the nearest hospital & GIS \\
\hline & & & \multicolumn{2}{|c|}{ DBIZ } & meter & $\begin{array}{l}\text { Distance to the nearest } \\
\text { business facilities }\end{array}$ & GIS \\
\hline & & \multirow{12}{*}{ Location } & \multicolumn{2}{|c|}{ DROAD } & meter & $\begin{array}{l}\text { Distance to the nearest trunk } \\
\text { road }\end{array}$ & GIS \\
\hline & \multirow{3}{*}{ Model 1} & & \multicolumn{2}{|c|}{ DCBD } & meter & Distance to CBD & GIS \\
\hline & & & \multicolumn{2}{|c|}{ DSQU } & meter & Distance to Tian'anmen Square & GIS \\
\hline & & & \multicolumn{2}{|c|}{ DSTA } & meter & $\begin{array}{l}\text { Distance to the nearest railway } \\
\text { station }\end{array}$ & GIS \\
\hline & \multirow[t]{3}{*}{ Model 2} & & $\mathrm{~T}$ & & & $\begin{array}{l}\text { Dummy variable indicating } \\
\text { that a residential area locates in } \\
\text { Tongzhou (1=yes) }\end{array}$ & \\
\hline & & & $\mathrm{Cr}$ & & & Interactive variable, $\mathrm{CY} * \mathrm{DSTA}$ & \\
\hline & & & & & & TZ*DSTA & \\
\hline & \multirow{5}{*}{ Model 3} & & \multicolumn{2}{|c|}{$\mathrm{TZ}$} & & & \\
\hline & & & \multicolumn{2}{|c|}{ CYE } & & $\begin{array}{l}\text { Dummy variable indicating } \\
\text { that a residential area locates in } \\
\text { the submarket of east to the } 5^{\text {th }} \\
\text { ring road in Chaoyang ( } 1=\text { yes })\end{array}$ & \\
\hline & & & $\mathrm{CY}$ & $\mathrm{ND}$ & & CYW*DSTA & \\
\hline & & & $\mathrm{CY}$ & & & CYE*DSTA & \\
\hline & & & $\mathrm{T} 2$ & & & & \\
\hline
\end{tabular}

The data collection strategy is as follows: sample collection: All new residential areas in our study area are listed based on real estate websites like http://www.e-fdc.com, http://www.soufun.com and http://house.sina.com.cn. data collection: The sale price, data on structure attributes and some 
neighborhood attributes are provided by the above websites. For the other variables especially location variables, the distances are measured by locating samples on the Beijing digital map of 2004 with the scale of 1:2000 based on field visit, and then overlapping the geographic distribution map of public service facilities.

\section{Data}

The samples include all new residential areas within $4 \mathrm{~km}$ of Batong line from June 2002 to April $2006^{12}$ (see Figure 8). The study area covers $195 \mathrm{~km}^{2}$, of which $115 \mathrm{~km}^{2}$ belongs to Chaoyang district and $80 \mathrm{~km}^{2}$ belongs to Tongzhou. The residential land accounts for $20 \%$ of the total land area.

The geographic distribution of samples can be seen from Figure 8. Obviously, the distribution density of new residential areas is high in the west and east side of Batong line, while low in the middle, which is the urban fringe of Beijing. The sample density in Chaoyang doesn't significantly differ with that in Tongzhou.

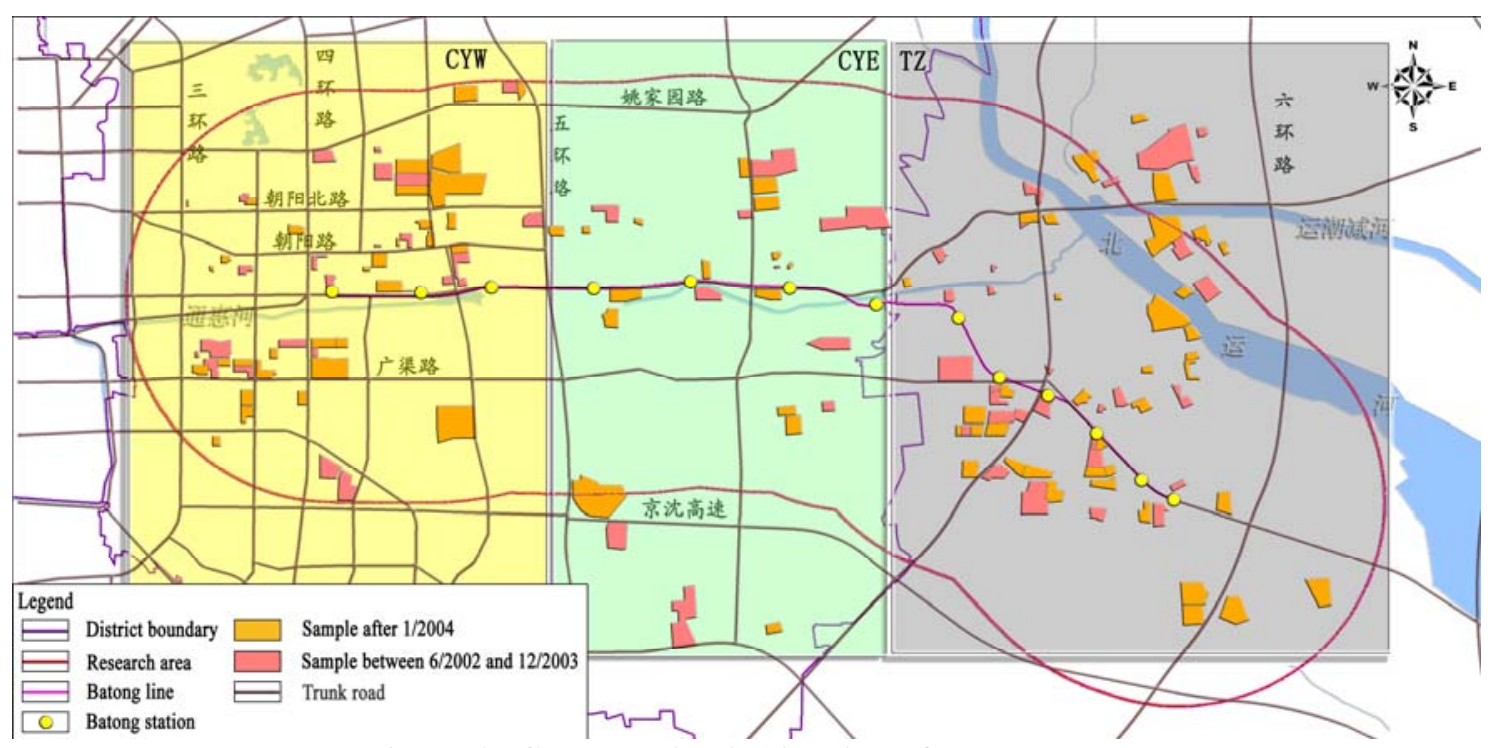

Figure 8: Geographic distribution of sample data

In our study, the specification of submarkets is entirely based on our knowledge of Beijing. Chaoyang and Tongzhou are two different districts. The $5^{\text {th }}$ ring road constitutes the boundary between urbanized area and villages of Chaoyang. As seen in Figure 8, the road density to the west of the $5^{\text {th }}$ ring road is enormously higher than that to the east. Surely, the results of multiple regressions using part samples also provide evidence for the specification of submarkets ${ }^{13}$. In Figure 8 , the boundary between these two districts specifies two submarkets, and the areas in different colors represent three submarkets.

As shown in Table 2, the data includes 141 observations for which all attributes could be obtained ${ }^{14}$. The average price is about 5205 yuan per $\mathrm{m}^{2}$. Of the total samples, the slab-type building accounts for more than $60 \%$. The average distance from new residential areas to railway stations is $1,864 \mathrm{~m}$. Considering different submarkets, the observations in Chaoyang submarket accounts for $52 \%$ of the total (the submarket of CYW and the submarket of CYE accounts for $35 \%$ and $17 \%$ respectively), and the observations in Tongzhou accounts for $48 \%$.

Table 2: Descriptive statistics of all data

\begin{tabular}{ccccc}
\hline & Minimum & Maximum & Average & SD \\
\hline PRICE & 1980 & 16000 & 5204.89 & 2674.93 \\
TIME & 54 & 100 & 76.62 & 12.13 \\
WAIT & 0 & 44 & 12.65 & 8.33
\end{tabular}

\footnotetext{
12 The given precondition is that the announcement of plan of Batong line in May 2002 has exerted impacts on real estate markets. Knaap, Ding and Hopkins (2001) confirm the pre-service impacts of rail transit plan.

${ }^{13}$ We also try to divide more submarkets according to the difference between the south side and the north side of Batong line, but don't obtain meaningful results.

${ }^{14}$ Professor Ming Zhang and Professor Zou both indicate that there is lack of abundant samples. We will amend it in future by using observations along Metro No. 13 and maybe all over Beijing.
} 


\begin{tabular}{ccccc}
\hline & Minimum & Maximum & Average & SD \\
\hline VILLA & 0 & 1 & .11 & .31 \\
SLAB & 0 & 1 & .62 & .49 \\
MIX & 0 & 1 & .18 & .38 \\
DECO & 0 & 1 & .21 & .41 \\
FAR & .33 & 12.50 & 2.3353 & 1.4048 \\
GREEN & 10.0 & 70.0 & 36.642 & 8.635 \\
FEE & .50 & 6.50 & 2.0252 & 1.1543 \\
DPARK & 450 & 8850 & 2843.33 & 1515.89 \\
DWAT & 0 & 5800 & 1636.31 & 1214.43 \\
DSCH & 50 & 2200 & 1007.94 & 505.59 \\
DHOS & 100 & 4700 & 1348.58 & 987.13 \\
DBIZ & 100 & 6750 & 1813.69 & 1379.00 \\
DROAD & 0 & 1900 & 525.32 & 463.55 \\
\hline DCBD & 0 & 21600 & 11149.15 & 6792.54 \\
DSQU & 5800 & 26800 & 16865.67 & 6824.14 \\
DSTA & 30 & 6400 & 1864.11 & 1382.48 \\
\hline TZ & 0 & 1 & .48 & .50 \\
\hline CYW & 0 & 1 & .35 & .49 \\
CYE & 0 & 1 & .17 & .38 \\
\hline Sample size & 141 & & & \\
\hline
\end{tabular}

Descriptive statistics of data in each submarket is shown in Table 3. Obviously, whether the price, the property service fee and the proportion of housing with decoration, or the accessibility to all kinds of facilities such as schools, all decrease from urban center to suburb. At the same time, FAR decreases from urban center to outskirt, while the green coverage ratio and the proportion of slab-type building both rise in this direction. All these phenomena conform to the theoretical expectation of urban economics, which shows that market has had great impacts on urban development of Beijing. As for the average distance to stations, there is not significant variation between these three submarkets.

Table 3: Descriptive statistics of data in each submarket

\begin{tabular}{c|cc|cc|cc} 
Submarket & \multicolumn{2}{|c|}{ CYW } & \multicolumn{2}{c|}{ CYE } & \multicolumn{2}{c}{ TZ } \\
Sample size & \multicolumn{2}{|c}{50} & \multicolumn{2}{c|}{24} & \multicolumn{2}{c}{67} \\
& Average & SD & Average & SD & Average & SD \\
PRICE & 7256.80 & 2768.28 & 4655.67 & 882.16 & 3870.36 & 2027.28 \\
TIME & 78.04 & 12.50 & 76.54 & 10.16 & 75.60 & 12.56 \\
WAIT & 13.02 & 6.87 & 13.63 & 8.58 & 12.03 & 9.26 \\
VILLA & .04 & .20 & .21 & .41 & .12 & .33 \\
SLAB & .52 & .50 & .63 & .49 & .70 & .46 \\
MIX & .28 & .45 & .08 & .28 & .13 & .34 \\
DECO & .42 & .50 & .17 & .38 & .07 & .26 \\
FAR & 3.1794 & 1.7900 & 1.9075 & .7577 & 1.8587 & .8778 \\
GREEN & 34.901 & 7.506 & 36.025 & 7.122 & 38.163 & 9.690 \\
FEE & 2.7802 & 1.2037 & 1.8640 & .4163 & 1.5195 & .9945 \\
DPARK & 1795.60 & 787.42 & 4634.58 & 1677.02 & 2983.58 & 1189.80 \\
DWAT & 1290.40 & 869.05 & 1881.25 & 1587.30 & 1806.72 & 1244.10 \\
DSCH & 908.40 & 454.31 & 1018.75 & 544.10 & 1078.36 & 522.72 \\
DHOS & 640.60 & 322.75 & 1431.25 & 1113.92 & 1847.31 & 960.48 \\
DBIZ & 726.00 & 563.84 & 1284.58 & 838.74 & 2814.93 & 1239.72 \\
DSTA & 1898.80 & 1024.37 & 1912.50 & 1753.15 & 1820.90 & 1483.37 \\
DROAD & 569.40 & 474.38 & 403.33 & 446.60 & 536.12 & 460.68
\end{tabular}

\section{Results}

Table 4 presents the regression results of three equations. The coefficients of TIME, DECO and FEE are significant in all three equations and conform to expectations. From 2002 to 2006, the initial average price 
of new residential areas rose by $3 \%$ every year ${ }^{15}$. The average price of housing with decoration is $5 \%$ higher than that without decoration. The average price will rise by $9 \%$ if property service fee increases by 1 yuan $/ \mathrm{m}^{2} \cdot$ month, which implies that residents along Batong line attach importance to the housing quality. This is also congruent with the survey conclusions by real estate companies. The coefficient of DBIZ is significant in Equation 1 and 3, which indicates the importance of the convenience of living near shops.

Interestingly, the effects of some variables are insignificant. The insignificance of the coefficients of WAIT and DHOS suggests residents along Batong line don't care the time devoted for waiting and the vicinity to a hospital ${ }^{16}$. As for DWAT and DSCH, the low value premium caused by these two factors is reasonable because the water quality of rivers in our study area is inferior and also there is no famous high school. The impact of DROAD is weak because this variable may be not appropriate for evaluating the level of road network. And the insignificance of the impacts of FAR suggests that this variable doesn't represent the housing quality well, which is also congruent with our experience. As for green coverage ratio, the national standard is no less than $30 \%$, so it is expected that for the economic consideration the green coverage ratio of most new residential areas just comply with the standard, which can be seen from low standard deviation in Table 2. So the insignificant impact of GREEN is acceptable. In addition, the results show that contrary to our expectation, the purchaser along Batong line pays little attention to the variation between different housing types except villa. However, as the average distance to urban center of towers is lower compared with slab-type buildings, perhaps the impacts of some unobserved location attributes weaken the value premium of slab-type buildings relative to towers.

Table 4: Results of three equations (Independent variable: log PRICE)

\begin{tabular}{|c|c|c|c|c|c|c|c|c|}
\hline \multicolumn{3}{|c|}{ Equation 1} & \multicolumn{3}{|c|}{ Equation 2} & \multicolumn{3}{|c|}{ Equation 3} \\
\hline Variable & Coefficient & t-stat & Variable & Coefficient & t-stat & Variable & Coefficient & t-stat \\
\hline Constant & $3.472 * * *$ & 62.514 & Constant & $3.325 * * *$ & 59.282 & Constant & $3.386^{* * *}$ & 57.598 \\
\hline TIME & $2.415 \mathrm{E}-03 * * *$ & 4.970 & TIME & $2.513 \mathrm{E}-03 * * *$ & 4.765 & TIME & $2.471 \mathrm{E}-03 * * *$ & 4.834 \\
\hline VILLA & $5.442 \mathrm{E}-02 *$ & 1.932 & VILLA & $4.541 \mathrm{E}-02$ & 1.494 & VILLA & $5.026 \mathrm{E}-02 *$ & 1.664 \\
\hline SLAB & $-1.493 \mathrm{E}-02$ & -.747 & SLAB & $-2.254 \mathrm{E}-02$ & -1.049 & SLAB & $-2.260 \mathrm{E}-02$ & -1.081 \\
\hline MIX & $4.882 \mathrm{E}-03$ & .210 & MIX & $-1.086 \mathrm{E}-03$ & -.043 & MIX & $-5.977 \mathrm{E}-03$ & -.242 \\
\hline DECO & $5.163 \mathrm{E}-02 * * *$ & 3.559 & DECO & $5.799 \mathrm{E}-02 * * *$ & 3.728 & DECO & $4.857 \mathrm{E}-02 * * *$ & 3.149 \\
\hline FEE & $9.150 \mathrm{E}-02 * * *$ & 14.076 & FEE & $9.772 \mathrm{E}-02 * * *$ & 14.244 & FEE & $9.617 \mathrm{E}-02 * * *$ & 14.364 \\
\hline DPARK & $-3.751 \mathrm{E}-06$ & -.801 & DPARK & $-1.670 \mathrm{E}-05 * * *$ & -2.928 & DPARK & $-2.128 \mathrm{E}-06$ & -.295 \\
\hline DBIZ & $-1.505 \mathrm{E}-05^{* *}$ & -2.250 & DBIZ & $-8.195 \mathrm{E}-06$ & -.973 & DBIZ & $-2.016 \mathrm{E}-05^{* *}$ & -2.243 \\
\hline DCBD & $-2.841 \mathrm{E}-06$ & -1.275 & $\mathrm{TZ}$ & $-3.376 \mathrm{E}-02$ & -1.202 & $\mathrm{TZ}$ & $-6.94 \mathrm{E}-02 * *$ & -2.241 \\
\hline DSQU & $-6.572 \mathrm{E}-06 * * *$ & -2.734 & & & & CYE & $-9.43 \mathrm{E}-02 * * *$ & -2.741 \\
\hline \multirow[t]{3}{*}{ DSTA } & $-3.213 \mathrm{E}-06$ & -.581 & TZD & $-1.787 \mathrm{E}-05^{*}$ & -1.903 & TZD & $-1.923 \mathrm{E}-05 * *$ & -2.007 \\
\hline & & & CYD & $1.690 \mathrm{E}-05^{*}$ & 1.926 & CYED & $1.450 \mathrm{E}-05$ & 1.316 \\
\hline & & & & & & CYWD & $3.722 \mathrm{E}-06$ & .328 \\
\hline Adjusted- $\mathrm{R}^{2}$ & 0.898 & & & 0.883 & & & 0.890 & \\
\hline
\end{tabular}

Then, we study the particular location attributes in these three equations. According to the results of Equation 1, the housing price will rise by $0.6 \%$ if the distance to Tian'anmen square decreases by $1,000 \mathrm{~m}$. The different impacts of DCBD and DSQU confirm the above viewpoint. For different submarkets, the location premium of Chaoyang submarket is not shown in Equation 2 for including much samples located in the village area (see the negative but insignificant coefficient of $\mathrm{TZ}$ in the result of Equation 2). But if

\footnotetext{
15 This may be lower than popular perception. However, it perhaps indicates that the increase of housing price along Batong line in recent years mostly attributed to the improvement of housing qualities.

${ }^{16}$ If the elder purchaser can be distinguished from the samples, maybe the effects of the vicinity to a hospital will be shown.
} 
these samples are eliminated, the CYW submarket will have the location premium of $7 \%$ higher compared with Tongzhou submarket as seen from the coefficient of TZ in the result of Equation 3.

As seen in the result of Equation 1, the impacts of Batong line on housing prices is not significant in the whole study area. However, when we divide the study area into two submarkets, the positive impact is found in Tongzhou located in suburb. That is, the housing price will increase by $1.8 \%$ if the distance to stations decreases by $1,000 \mathrm{~m}^{17}$. While for Chaoyang submarket, we cannot separate the effect of DSTA from $\mathrm{CY}$ because $\mathrm{CYD}=\mathrm{CY}{ }^{*} \mathrm{DSTA}$ and $\mathrm{CY}$ is not included in Equation $2^{18}$. Therefore, we run the regression with the subsample of Chaoyang only (with the adjusted- $\mathrm{R}^{2}$ of 0.873 ). The estimated coefficient of DSTA is $-3.24 * 10^{-6}$ (with t-statistics of -0.230 ), which shows the weak impact of rail transit in Chaoyang situated near urban center. Equation 3 also confirms the greater impacts of rail transit in suburb than that in urban center. However, subdividing Chaoyang into two submarkets doesn't provide more meaningful information ${ }^{19}$.

In a word, the submarket effect certainly has significant effect on the conclusions of related studies. In addition, we should notice that the impact of rail transit on housing values in suburb is greater than that in urban center according to our study. While the empirical study by Kim and Zhang (2005) shows that the reverse is true for commercial and office properties. So we guess that the contradiction in viewpoints actually is just the different exhibitions of submarket effect for different types of properties. Why so? We will try to explain it using Effect I and Effect $I I$ defined in Section 3.

For different types of properties, there may be little difference in the impact of Effect $\Pi$. But due to the different gradients of bid-rent curves, the impact of Effect I on commercial and office properties is greater than that on residential properties, which can easily be proved mathematically. And this will ultimately shift the relative magnitude of these two effects. As for commercial and office properties, the impact of Effect I is greater than that of Effect $\Pi$, which causes the value premium higher in CBD than that in suburb. While for the residential, the impact of Effect $I I$ dominates so the premium in suburb is higher (see Figure 9). This phenomenon is easy to comprehend intuitively. By strengthening the linkage between urban center and suburb, rail transit like Batong line further improve the dominant position of commercial and office sector located in urban center within the whole city. For instance, the residents in Tongzhou now probably prefer shopping in urban center where they can enjoy better service. Thus, the value premium of commercial and office properties in urban center will be higher than that in suburb. On the other hand, compared with residents in urban center who already has easy access to employment opportunities, the residents in suburb now can arrive at the employment center more conveniently as a result of rail transit, so the increase in bid-rents for outskirt housing will be higher than that in CBD.

Note that the above analysis is only our conjecture, which needs to be confirmed by more theoretical analysis and empirical evidence. For example, if our explanation is true, how much is these two effects respectively?

\footnotetext{
17 It is lower than expectations. It can attribute to: the low service quality of Batong line (low speed, long interval, small capacity and requiring the assistance of other transportation vehicles for lacking of rail transit network); multiple trunk roads between Tongzhou and central city; mature bus system including own regular bus of residential areas. So as for Batong line, there is no advantage relative to other transportation modes. Based on the transportation survey report of Tongzhou New Town by BMICPD in January 2006, of the passenger traffic between Tongzhou and central city, bus accounts for $54.7 \%$, car accounts for $30.8 \%$ and metro just $14.5 \%$.

${ }^{18}$ I thank Professor Ming Zhang for indicating the error in the draft paper and advising to run the regression with the subsample only.

${ }_{19}$ We also do similar regressions for 78 observations after the operation of Batong line (samples in yellow in Figure 8). The results show that the impact of rail transit on property values in Tongzhou is greater after the operation. Now the housing price will increase by $3.8 \%$ if the distance to stations decreases by $1,000 \mathrm{~m}$. Thus, the impacts in whole study area now become significant (about 1.4\%, with p-statistics of 0.10 ). We will further analysis the variation of rail transit's impacts with time in future.
} 

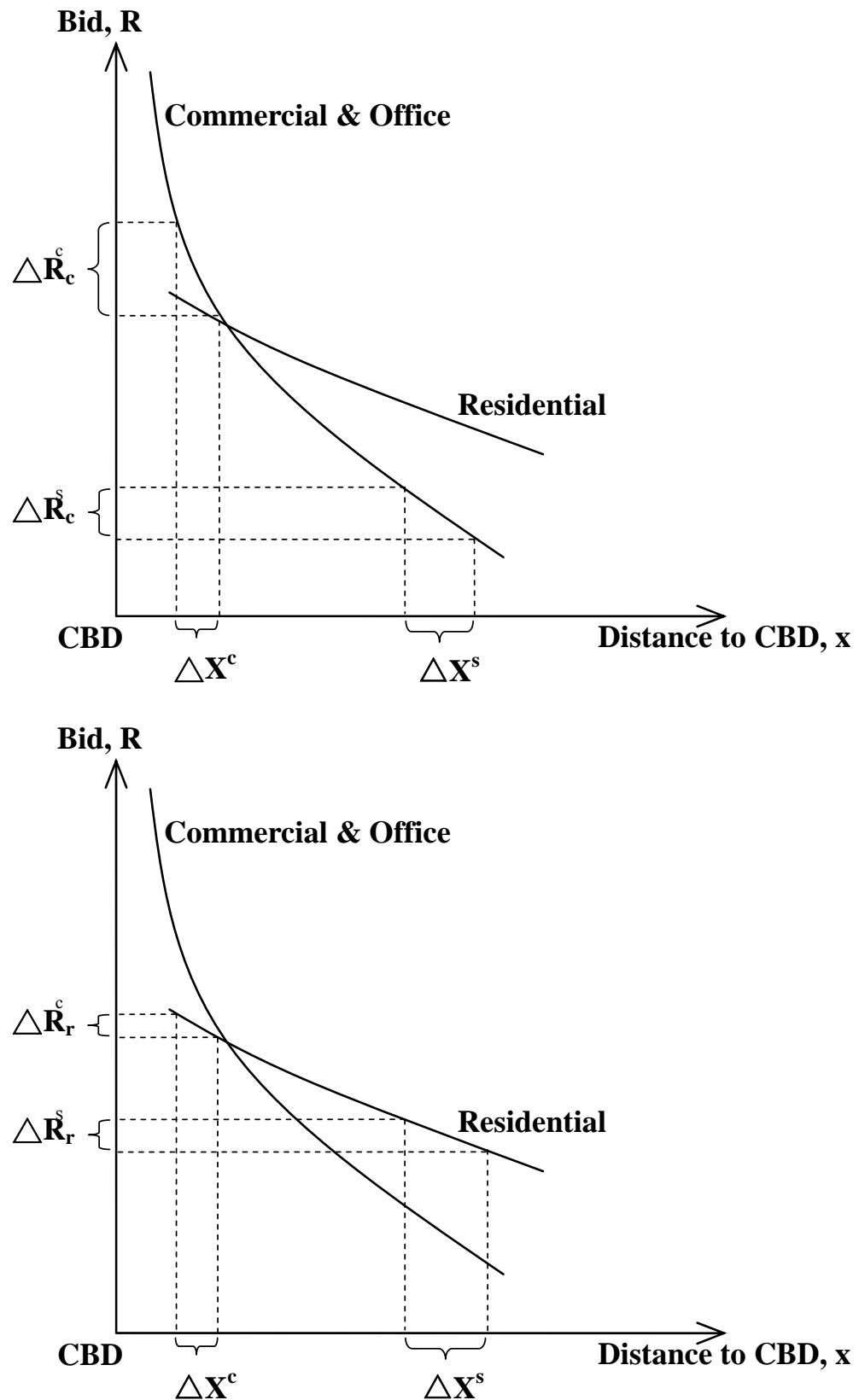

Figure 9: Different impacts of rail transit on commercial \& office properties (top)and residential properties (bottom)

\section{Conclusions}

The results of our empirical study show that the submarket effect is an import factor that causes the mixed conclusions of related studies. Between June 2002 and April 2006, the impact of Batong line on housing prices is insignificant in the whole study area, while the positive effect is found in part area. Furthermore, the impact on housing prices in suburb is greater than that in CBD. In Tongzhou far from urban center, the housing price will increase by $1.8 \%$ every $1,000 \mathrm{~m}$ nearer to railway stations. While in Chaoyang, whether close to railway stations or not has only weak impacts on housing prices.

The submarket effect in different locations is the integration of two opposite effects. The Effect I, which comes from the convexity of bid-rent curve, causes the greater impact of rail transit in CBD than that in suburb. However, the Effect $\Pi$ originating from the law of diminishing marginal returns produces the opposite impact. The difference between the bid-rent gradients of the commercial and office sector and that of the residential not only causes different impacts of rail transit on different property types, but also 
essentially shifts the relative magnitude of these two effects. As for the commercial and office property, the impact of the Effect $I$ is greater than that of Effect $I$, that causes the value premium higher in CBD than that in suburb. While for the residential, the impact of Effect II dominates so the premium in suburb is higher.

Except the insufficiency of samples, there are still many shortcomings in our research, such as: (1)not considering spatial autocorrelation; and (2)lacking of strong evidence for the specification of submarkets. Additionally, the analysis and explanation of submarket effects is only our conjecture, which calls for more studies. Also we should pay more attention to the impacts of rail transit on commercial and office properties, for which there have been few studies, especially in China.

\section{Acknowledgements}

I thank the China Program at Lincoln Institute of Land Policy for financial support. And I have benefited from helpful comments from Chengri Ding, Liqun Du, Xiaolu Gao, Yan Song, Ge Wu, Ming Zhang, Wenzhong Zhang, Ji Zou, a number of seminar participants, and my colleagues at BMICPD. I also thank Rui Guo for her excellent research assistance. Any errors or shortcomings in the paper, however, are my responsibility.

\section{References}

Alonso, W. 1964. Location and Land Use. Cambridge, MA: Harvard University Press.

Al-Mosaind, M.A., Duecker, K.J. and Strathman, J.G. 1993. Light-rail Transit Stations and Property Values: A Hedonic Price Approach. Transportation Research Record 1400: 90-94.

Benjamin, J.D., Sirmans, G.S. 1996. Mass Transportation, Apartment Rent and Property Values. Journal of Real Estate Research 12(1): 1-8.

BMICPD. 2006. Transportation Survey of Tongzhou New town, Beijing (in Chinese). Working report.

Beijing Urban Master Plan (2004-2020). 2004.

Cervero, R., Landis, J. 1993. Assessing the Impacts of Urban Rail Transit on Local Real Estate Markets Using Quasi-Experimental Comparisons. Transportation Research A 27(1): 13-22.

Diaz, R.B. Impacts of Rail Transit on Property Values. 1999. APTA 1999 Rapid Transit Conference Proceedings Paper.

Gatzlaff, D.H., Smith M.T. 1993. The Impact of the Miami Metrorail on the Value of Residences Near Station Locations. Land Economics 69(1): 54-66.

Goodman, A.C., Thibodeau, T.G. 1998. Housing Market Segmentation. Journal of Housing economics 7: 121-143.

Huang, H. 1996. The Land-use Impacts of Urban Rail Transit Systems. Journal of Planning Literature 11(1): 54-66.

He, Y., Jin, C.H. 2001. Policy Support for the Development of Urban Rail Transportation (in Chinese). Urban Rail Transit Research (2): 12-15.

Knaap, G.J., Ding, C. and L.D. Hopkins. 2001. Do Plans Matter? The Effects of Light Rail Plans on Land Values in Station Area. Journal of Planning Education and Research 21(1): 32-39.

Kim, J., Zhang, M. 2005. Determining Transit's Impact on Seoul Commercial Land Values: An Application of Spatial Econometrics. International Real Estate Review 8(1): 1-26.

Landis, J., Guhathakurta, S., Huang, W. and M. Zhang. 1995. Rail Transit Investments, Real Estate Values, and Land Use Change: A Comparative Analysis of Rive California Rail Transit Systems, Monograph, 48. Institute for Urban and Regional Development, University of California: Berkeley, CA.

Lesage, J.P. 1999. The Theory and Practice of Spatial Econometrics. http://www.spatial-econometrics.com.

Li. Y.Z. 2005. Some Thoughts on Planning and Scale of Urban Rail Transit in China (in Chinese). Urban Rapid Rail Transit 18(4): 83-85.

Nelson, A.C. 1999. Transit Stations and Commercial Values: A Case Study with Policy and Land-Use Implications. Journal of Public Transportation 2(3): 77-93.

O’Sullivan, A. 2002. Urban Economics, 4e. Beijing: CITIC Publish House.

Rosen, Sherwin. 1974. Hedonic prices and implicit markets: Product differentiation in pure competition. Journal of Political Economy 82(1): 35-55.

Sheppard, S. 2003. Hedonic Analysis in Real Estate Market (in Chinese). In Handbook of Regional and Urban Economics, Vol.3. ed. P. Cheshire, E.S. Mills. Beijing: Economic Science Press. 
Wang, X., Zhu, D.L. and M.M. Zhang. 2004. The Impacts of Urban Rail Transit on Property Values: Case Study of Light Rail No.13 (in Chinese). Urban Problems (6): 39-42.

Zhang, M. 1999. Capture the Marginal Accessibility Effects of Rail Transit Systems - A Boston Case Study. Unpublished.

Zheng. J.F., Liu, H.Y. 2003. The Effects of Rail Transit Construction on Nearby Housing in Shenzhen (in Chinese). Proceedings of 2003 Symposium on Property Evaluation of China: 104-114. 